\title{
Incidence of multiple births in an Indian rural community
}

\author{
A. R. JUNNARKAR AND M. G. NADKARNI \\ From the Department of Preventive and Social Medicine, Grant Medical College, Bombay
}

SUMMARY In this paper we report on the incidence of multiple births in a rural community of India in the period 1966-75. The incidence is an improvement on estimates reported earlier by various authors and the information would be useful for studying secular trends.

A multiple birth is a birth of two or more babies in one parturition. Several investigators have in the past reported on the incidence of multiple births in various urban Indian communities (Park, 1966; Bulmer, 1970; Dutta, 1972; Bhalla et al., 1977; Shrivastav et al., 1977). These reports were based on births occurring in public maternity hospitals and maternity centres. In Indian communities domiciliary confinements are common and routine birth registrations are incomplete and unreliable. To obtain true information on births, therefore, special techniques need to be adopted, like strengthening the routine reporting machinery and closely supervising and periodically correcting birth registers by community inquiry. The reports in this paper are based on information collected in 1966-75, using the above techniques, in 26 villages of Palghar Block (latitude $20^{\circ}$ north, longitude $74^{\circ}$ east).

These villages form the operational area of the rural field training centre attached to Grant Medical College, Bombay. The size of the area is approximately $137.28 \mathrm{~km}^{2}$. It is served by a team of 60 paramedical field workers under the close supervision and guidance of four medical officers and a reader in preventive and social medicine in charge of the rural field training centre. In the 1971 census the population of the area was 67900 .

Information on births in the community was collected and recorded by field workers. To ensure that all births were recorded, the help was also sought of 125 indigenous Dias who conduct a number of deliveries in the area. House-to-house inquiries were made in each village each year to make good any deficiencies in the birth records. The results are shown in Table 1.

The crude multiple birth ratio in Indian communities varies from 8.7 to 11.53 per 1000 maternities, as reported by Park et al. (1966), Dutta
(1972), and Bhalla et al. (1977). The figures reported in this study are an improvement on available estimates; moreover, these figures apply to a rural community. Birth registration is incomplete in rural India, so periodic studies of this nature may throw some light on secular trends.

If the sex distribution of twins in a population is known, it is possible to calculate the number of monozygotic (MZ) and dizygotic (DZ) twins (Table 2) by applying Weinberg's differential formula,

Table 1 Multiple births in 26 Indian villages 1966-75

\begin{tabular}{llll}
\hline $\begin{array}{l}\text { Population } \\
\text { (1971 census) }\end{array}$ & $\begin{array}{l}\text { Total no. of } \\
\text { maternities }\end{array}$ & $\begin{array}{l}\text { Total no. of } \\
\text { multiple births }\end{array}$ & $\begin{array}{l}\text { Multiple } \\
\text { birth ratio }\end{array}$ \\
\hline 67900 & 17085 & 154 & 9.01 \\
\hline
\end{tabular}

Table 2 Twinning by zygosity in 26 Indian villages 1966-75, using Weinberg's differential formula

\begin{tabular}{|c|c|c|c|c|c|}
\hline \multicolumn{3}{|c|}{ Sex of twins } & \multirow[b]{2}{*}{ Total } & \multirow[b]{2}{*}{$M Z(\%)$} & \multirow[b]{2}{*}{$D Z(\%)$} \\
\hline$M M$ & $\boldsymbol{F F}$ & $M F$ & & & \\
\hline 56 & 61 & $37^{*}$ & 154 & 51.9 & $48 \cdot 1$ \\
\hline
\end{tabular}

- Including one triplet (MFF).

which assumes that the number of $\mathrm{DZ}$ twins in a population equals twice the number of unlike-sexed twins. If, therefore, like-sexed twin maternities are observed as $\mathrm{L}$ and unlike-sexed twin maternities as $\mathrm{U}$, then the number of $\mathrm{DZ}$ twin maternities is taken as $2 \mathrm{U}$ and the number of $\mathrm{MZ}$ twin maternities as $\mathrm{L}-\mathrm{U}$.

Bulmer (1970) reported that the $M Z$ twinning rate was constant for all communities, lying between 3.5 and $4 \cdot 0$, although this cannot be a rule. The $M Z$ rate reported in this study is 4.7 (Table 3 ), showing a 
variation of $17 \%$ above the maximum figure quoted by Bulmer. This $\mathrm{MZ}$ twinning rate of 4.7 and the $\mathrm{DZ}$ twinning rate of 4.3 also reported in this study are improvements on the available estimates of 3.7 and 7.4 respectively for Indian communities reported by Bhalla et al., (1977) and others.

Table 3 Twinning rate by zygosity in 26 Indian villages 1966-75

\begin{tabular}{lll}
\hline & \multicolumn{2}{l}{ Zygosity 1000 maternities } \\
\cline { 2 - 3 } Rate & $M Z$ & $D Z$ \\
\hline 9.01 & 4.68 & 4.33 \\
\hline
\end{tabular}

Reprints from A. R. Junnarkar, Department of Preventive and Social Medicine, Miraj Medical College, Miraj, Sangli District, Maharashtra, India, PIN CODE No. 416410.

\section{References}

Bhalla, J. N., Bhalla, M., and Shrivastav, J. R. (1977). A study of some maternal factors associated with twinning. Indian Pediatrics, 14, 539-543.

Bulmer, M. G. (1970). The Biology of Twinning in Man. Clarendon Press: Oxford.

Dutta, I. (1972). A study of twin births in Jabalpur City. Indian Journal of Pediatrics, 39, 15-19.

Park, J. H. (1966). Observations on twin births in Gwalior City. Indian Journal of Pediatrics, 33, 39-43.

Shrivastav, J. R., Bhalla, M., and Bhalla, J. N. (1977). A study of twins. Indian Pediatrics, 14, 121-127. 